\section{Population Growth of Two Types of Rotifer (L and S) Brachionus plicatilis at Different Dissolved Oxygen Levels}

Short Papers

\author{
Shigehisa Yamasaki,* David H. Secor,* \\ and Hachiro Hirata*
}

(Accepted October 16, 1986)

Low dissolved oxygen levels (DO) are associated with a decrease in growth and conversion rates of reared fin-fish and crustaceans., ${ }^{1,2)}$ It was also suggested that pollution of rearing water was accelerated by a decrease in conversion rates in reared organisms. ${ }^{3)}$ This is especially serious for rotifers which show higher food consumption rates than other mass cultured organisms. ${ }^{4}, 5$ ) In the experiments reported here, food conversion rates were compared between $L$ and $S$ type rotifers exposed to three different DO levels. DO level at which food conversion was most efficient, was determined for each type of rotifer.

The L-type rotifers have been cultured in our laboratory since 1964, when they were isolated from Yashima Bay. Rotifers of S-type were isolated from cultures obtained from the Shibushi Station (Japan Farming Fisheries Association) in 1984. The three levels tested were $6.1 \pm 1.1,2.3 \pm 0.5$, and $0.9 \pm 0.3 \mathrm{mg} / l$ and were obtained by bubbling the mixture of nitrogen gas with air. Rotifers were cultured in $10 \mathrm{l}$ plastic aqualia with an initial density of 20 individuals per $\mathrm{ml}$ (ind $/ \mathrm{ml}$ ) and $40 \mathrm{ind} / \mathrm{m} l$ for $L$ and $S$ type rotifers, respectively. The rotifer density was determined daily in each culture by counting and was readjusted to the initial density by removing surplus rotifers. Culture was continued without readjustment of the density in the case of negative growth. A stock of concentrated marine Chlorella obtained by centrifuging the cultured alga, was stored at $3^{\circ} \mathrm{C}$ and used as food in the course of experiments. The amount of Chlorella supplied to rotifers was 1.23 and $0.57 \mu \mathrm{g} /$ ind/day in dry weight base for $\mathrm{L}$ and $\mathrm{S}$ type rotifers, respectively; equivalent to $300 \%$ of rotifer body weight. The density of Chlorella remaining in the culture was determined daily in each container and new algae were supplied to meet the intended food levels. Rotifers were adapted for
3 days to the experimental conditions prior to the twoweeks experiments. Experiments were repeated two times for each treatment. Food conversion rates were calculated by dividing the total weight of rotifers harvested by the total amount of food supplied to each treatment in the course of the experiments.

Results show that daily population growth rates for L-type rotifers at tested high DO levels were higher than those at low DO levels (Table 1). Negative growth rates were observed at $0.9 \mathrm{mgO}_{2} / l$, On the other hand, no significant difference was observed for S-type population growth among the three DO levels employed. Similar trends were also observed for food conversion rates. It is clear that, for L-type rotifers, the proportion of food materials which are not utilized for the body construction increases at lower DO content. In other words, the proportion of food materials which contribute to the water pollution increases as DO in the culture water decreases.

In conclusion, efficient food conversion rate was obtained around saturation levels of DO for L-type rotifers. Although the food conversion rates for $\mathrm{S}$ type rotifers were found to be almost constant above $0.9 \mathrm{mgO}_{2} / l$, DO level should be kept stable at a low DO content ${ }^{6)}$; a rapid decrease in density was also observed even in S-type rotifer when the DO dropped suddenly from 2.3 to $0.8 \mathrm{mg} / \mathrm{l}$ in one day on one occasion in this experiment.

The authors wish to thank Dr. E. Lubzens for her critical reading of the manuscript.

\section{References}

1) K. Chiba: in "Respiration and blood circulation system of fish" (ed. by Japan. Soc. Sci. Fish.), Koseisya-Koseikaku, Tokyo, 1978, pp. 96-110.

2) S. Rowchai, K. Chiba, and R. Hirano: Nippon Suisan Gakkaishi, 52, 597-607 (1986).

3) S. Yamasaki and H. Hirata: Aquiculture, 32, 225-229 (1985).

4) K. Hirayama and S. Ogawa: Nippon Suisan Gakkaishi, 38, 1207-1214 (1982).

5) H. Hirata: Yousyoku, 17 (3), 35-38 (1980).

6) O. Imada: in "The Rotifer Brachionus plicatilis -Biology and Mass Culture" (ed. by Japan. Soc. Sci. Fish.), Koseisya-Koseikaku, Tokyo, 1983, pp. 129-155.

Table 1. Daily population growth rates in number (PG) and food conversion rates (FC) of $L$ and $\mathrm{S}$ type rotifers as related to $\mathrm{DO}$ in the culture (mean $\pm \sigma, \%)$

\begin{tabular}{|c|c|c|c|c|c|c|c|c|}
\hline \multicolumn{2}{|c|}{$\mathrm{DO}(\mathrm{mg} / \mathrm{l})$} & \multicolumn{2}{|c|}{$6.1 \pm 1.1$} & \multicolumn{2}{|c|}{$2.3 \pm 0.5$} & \multicolumn{2}{|c|}{$0.9 \pm 0.3$} & \multirow{2}{*}{$\begin{array}{l}\text { Culture } \\
\text { period } \\
\text { (days) }\end{array}$} \\
\hline Types & Trial & PG & $\mathrm{FC}$ & PG & $\mathrm{FC}$ & PG & FC & \\
\hline L type & II & $\begin{array}{r}39 \pm 10 \\
108 \pm 41\end{array}$ & $\begin{array}{l}11 \\
27\end{array}$ & $\begin{array}{l}20 \pm 35 \\
29 \pm 42\end{array}$ & $\begin{array}{l}4 \\
9\end{array}$ & $\begin{array}{r}-31 \pm 46 \\
-4 \pm 23\end{array}$ & $\begin{array}{l}-7 \\
-2\end{array}$ & $\begin{array}{r}5 \\
14\end{array}$ \\
\hline S type & $\begin{array}{l}\text { I } \\
\text { II }\end{array}$ & $\begin{array}{l}78 \pm 38 \\
91 \pm 58\end{array}$ & $\begin{array}{l}28 \\
24\end{array}$ & $\begin{array}{l}84 \pm 36 \\
54 \pm 24\end{array}$ & $\begin{array}{l}32 \\
23\end{array}$ & $\begin{array}{l}78 \pm 34 \\
62 \pm 42\end{array}$ & $\begin{array}{l}34 \\
24\end{array}$ & $\begin{array}{l}14 \\
14\end{array}$ \\
\hline
\end{tabular}

$\mathrm{WT}=23 \pm 1^{\circ} \mathrm{C}, \mathrm{pH}=7.5 \pm 0.3, \mathrm{~S}=20 \mathrm{ppt} ; 50 \mathrm{lux}(15 \mathrm{~L}: 9 \mathrm{D})$

* Laboratory of Fish Cultivation Physiology, Faculty of Fisheries, Kagoshima University, Kagoshima, 890 Japan. (山崎繁久, デビッドセコア, 平田入郎: 鹿先岛大学水産学部). 